\title{
Determinants of Income Diversification and Its Effects on Household Income in Rural Vietnam
}

\author{
TRÀ̀ TIẾN KHAI \\ University of Economics HCMC - trankhai565@yahoo.com \\ NGUYẼ̃N NGỌC DANH \\ University of Economics HCMC - ngocdanh2001@yahoo.com
}

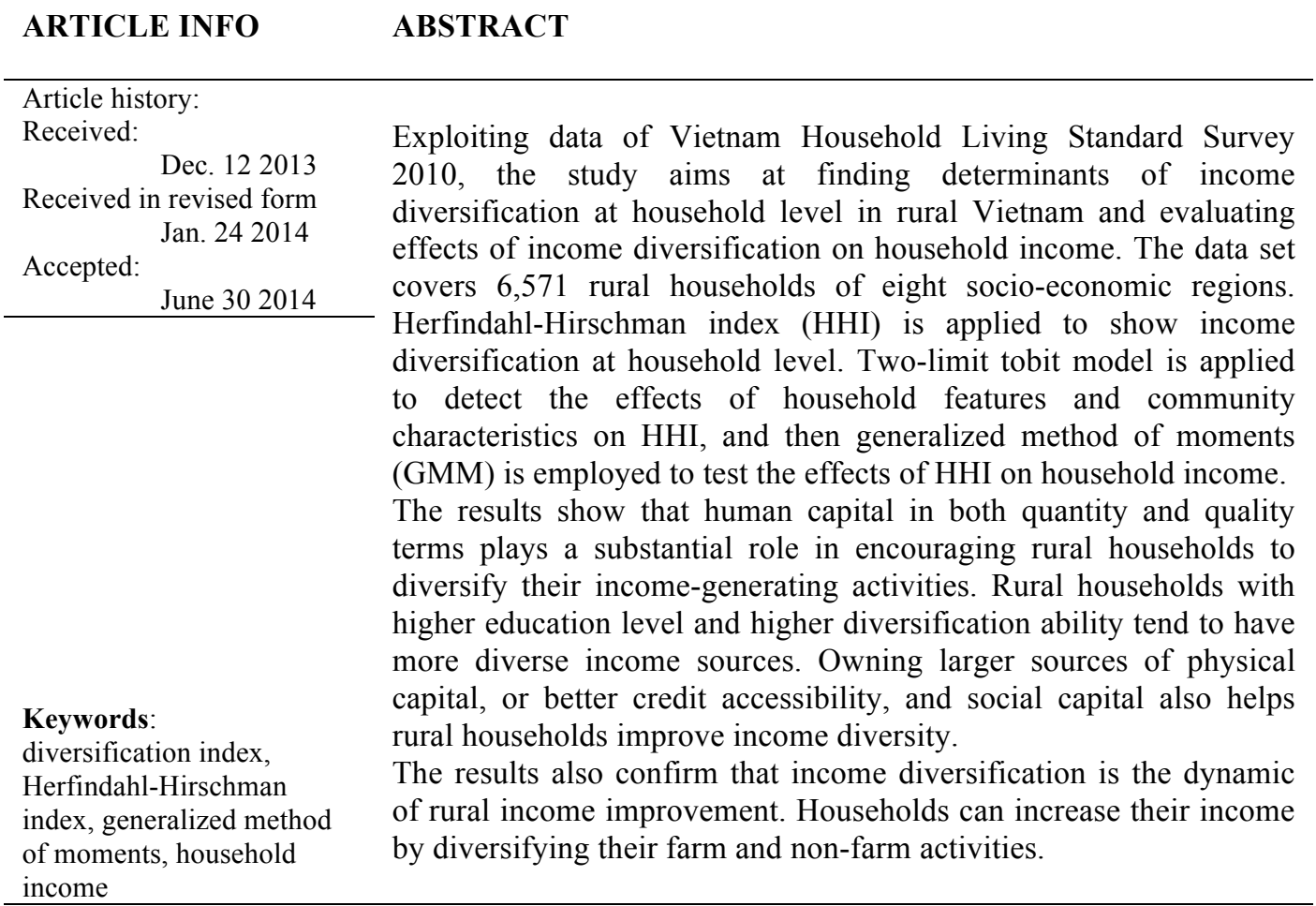




\section{INTRODUCTION}

Vietnam is on the process of industrialization. By increasing shares of manufacturing and service sectors in the GDP, labor surplus from agricultural sector is expected to be strongly absorbed. However, during 20 years of renovation, the speed of labor movement out of agriculture has been slow. Pressure of labor on land resource is still not reduced and hence the small-scale farms with low labor productivity are main features of rural Vietnam. Consequently, the rural households adapt the situation by reallocating their scare resources into diversified non-agricultural economic activities to search additional income.

From economic theories, world empirical experiences, and policy makers' viewpoint, income diversification is considered a channel to escape poverty in rural areas. However, it is still unclear what motives of income diversification in rural areas; are how rural households diversify their income under a given specific internal resources and external conditions; and in land scarcity context of rural Vietnam, whether income diversification is an ideal solution to improve household income.

Therefore, this study aims to examine the determinants of income diversification, and the links between income diversification and household income in the rural Vietnam, especially over the economic recession period 2008-2010 caused by the global financial crisis. Specifically, two research questions are raised: (i) what are the determinants of income diversification? and (ii) how is the links between income diversification and household income in the rural Vietnam?

The study is structured as follows: Section 2 is devoted to review of diversificationrelated issues in previous studies. The basic regression specification is discussed in the next section. Section 4 provides an empirical analysis of the factors driving income diversification in the rural Vietnam as well as the empirical findings of the effect of income diversification on household income. The final section is for conclusion and policy implication.

\section{THEORETICAL BASIS AND ANALYTIC FRAMEWORK}

\section{a. Income Diversification Definition and Its Measurements:}

Firstly, income diversification is defined simply as a process in which multiple income sources are created by a rural household (Minot et al., 2006). Proxy indicator is the number of income sources of each household at a given time. Although this indicator is closest to the original meaning of the word, it only reflects income-generating activities. Secondly, income diversification is defined as a process in which rural households increase their 
employment and income from the non-farm activities. Regarding this, either the share of time spent on or the share of earnings from non-farm activities is used to highlight the importance of non-farm income in a household's livelihood (Barrett \& Reardon, 2001; Barrett et al., 2001; Davis \& Bezemer, 2003; Ellis, 2000; Lanjouw \& Feder, 2001). The Simpson index, the Herfindahl index, and the inverse Herfindahl index are proposed to capture a process in which households not just increase the number of sources but also get greater balance in term of share of income sources in their income portfolio (Ellis, 2000; Joshi et al., 2003; Minot et al., 2006).

Given the above discussion, inverse Herfindahl index (also called HerfindahlHirschman index) is the most appropriate measurement because: (i) it takes into consideration both the number of income sources and the contribution of each source to total household income, and (ii) most main motives of diversification are income maximization or income stabilization.

$$
H H I=1-H I=1-\sum_{i=1}^{n} P^{2}
$$

\section{b. Determinants of Income Diversification:}

\section{Determinants of income diversity in push/pull factors}

The theoretical discussion often categorizes the drivers of income diversification to push/pull factors (Barrett et al., 2001; Davis, 2003; Davis \& Bezemer, 2003; Ellis, 2000; Haggblade et al., 2002; Start, 2001). The "push factors" terminology refers external factors, changes of which cause the fluctuation of farm income (e.g. weather conditions, policy changes, etc.), which in turn leads to the increase in household's motivation in adopting income diversification strategy to mitigate the adverse effect of these factors. The "pull factors" refers to growth opportunities in term of household income (Barrett et al., 2001; Barrett \& Reardon, 2001). For instance, households are more likely to increase their income when favorable changes exist (e.g. education, infrastructure conditions, and gender) (Barrett et al., 2001; Lanjouw \& Lanjouw, 2001). Household income diversification strategy is affected by push factors rather than pull factors. Moreover, pull factors may play complementary roles for push factors in facilitating income diversification (Barrett et al., 2001; Ellis, 2000). Reardon et al. (2007) point out the dynamic interactive process between pull and push factors.

\section{Determinants of income diversity in income sources}


Risk reduction: A household tends to reallocate its productive asset to several activities to avoid risk or loss correlated with its fundamental income (Dercon \& Krishnan, 1996; Ellis, 2000; Barrett \& Reardon, 2001; Start, 2001). Households often choose new activity such as raising cattle and/or non-farm activities to cope with weather shocks (Reardon, Matlon \& Delgado, 1988; Dercon, 1998). Income diversification typically occurs due to instability of income sources and risk-averse behavior of household. The empirical findings often show that poor rural households are more likely to have diverse income sources than richer households (Barrett, Bezuneh \& Aboud, 2001; Block \& Webb, 2001; Joshi et al., 2003).

Meeting consumption needs: In the context of resource and/or market constraints, the household is motivated to diversify with a view to getting earning to a level that would be able to meet their basic needs (Dunn, 1997; Ellis, 2000; Barrett \& Reardon, 2001; Start, 2001). Moreover, if a household lives in remote areas where the cost of goods exchange will be very high, diversification is also a strategy to satisfy demand for goods of household as well as community (Singh, Squire \& Strauss, 1986; Omamo, 1998).

Moreover, income diversification is considered as a household's strategy to cope with diminishing marginal returns to labor problem, especially in rural areas whereas seasonal unemployment is common. Furthermore, income diversification could be employed to reduce risk or to fulfill the increasing basic needs of households, which depends on the research circumstances. For instance, Asian farmers diversify away from rice into highervalue crops and activities to boost their income, while African farmers' diversification motivation is risk reduction (Delgado \& Siamwalla, 1997). Moreover, in Zimbabwe, Ersado (2003) finds that the higher intention to diversify income is found for rich households in rural areas rather than the ones in urban areas.

\section{Diversification as commercialization process}

The welfare of diversified households is better than that of those which have only one or a few fundamental income sources, but diversified households are expected to have more assets, less risk-averse behavior to cope with the high variation in term of price of both commercial crop and foods. Therefore, poor farmers face more constraints to participate in commercial production due to their liquidity constraints. Thus, farmers who live in more remote areas or sparsely populated areas rely more self-sufficiently and less on commercial production (Omamo, 1998; Minot, 1999).

\section{Diversification into non-farm activities}


Many empirical evidences in Asia and Latin American show that the fundamental income source of poor households is from agricultural sector, while non-poor households are more likely to participate in wage-earning and off-farm jobs (FAO, 1998; Lanjouw \& Lanjouw, 2001). The development of rural infrastructure could increase the likelihood of poor households to engage in non-farm activities. Empirical evidence shows that the increase of non-farm share positively associates with development of electricity network (Reardon, 1997; Escobal, 2001; Lanjouw \& Lanjouw, 2001). However, the development of road network in rural areas has mixed effects. On one hand, local non-farm businesses are threatened because imported goods are likely to be cheaper (Haggblade, Hazell \& Reardon, 2002). On the other hand, the cost of imported inputs from urban area is also likely to be reduced, as well as the non-farm businesses have more market development opportunities. The latter effect is greater in regions being closer to urban ones (Reardon, 1997; Escobal, 2001; Lanjouw \& Lanjouw, 2001). Similarly, the expansion of formal credit market could have mixed effects on household's income diversification strategy. The less-effective aspect of formal credit market could constrain rural households to engage in high-income non-farm activities but support low-income non-farm activities (FAO, 1998).

\section{Diversification into high-value activities}

Income diversification is also defined as a process of switching low-value activities to high-value ones. This process could be hindered by lack of credit accessibility, market information, appropriate production technology, human capital, public infrastructure, social capital, and household's productive assets. In other words, the insufficiency of these meso-level factors could limit the likelihood to diversify into high-value non-farm activities (Barrett \& Reardon, 2001; Davis, 2003; Ellis, 2000; Lanjouw \& Feder, 2001; Reardon et al., 2007). Thus, proximity to towns, access to road, electricity and water are often used as proxies for these meso-level factors (Barrett et al., 2001; Ellis, 1998; Reardon et al., 2007).

\section{Determinants of income diversification in household assets}

The critical role of household productive assets is emphasized in the study of Reardon et al. (2007). Firstly, household's human capital (in terms of quality as well as quantity) is a critical factor of its engagement in non-farm activities (Carney et al., 1999; Ellis, 2000, Reardon et al., 2007). More particularly, the households with higher education level or with more workers are more likely to participate in (high-value) non-farm activities 
(Abdulai \& Delgado, 1999, Ellis, 1998; Reardon, 1997). Secondly, although landholding is positively associated with farm income and greater likelihood of credit accessibility, but its effects on income diversification are mixed. Landholding could encourage rural households to increase their income capacity by not only adopting new non-farm activities (Abdulai \& CroleRees, 2001) but also intensifying farm activities (Minot et al., 2006). Thirdly, financial capital constraints often prevent poor households from engaging in highvalue non-farm activities (Ellis, 2000). Because of the ineffectiveness of formal credit market in rural areas, the value of productive assets could be employed as proxies for financial capacity of household (Escobal, 2001). Lastly, social capital refers to the relation networking of households, which is hard to measure (Ellis, 2000). Some empirical studies assign some categorized variables as proxies, such as membership in organizations and "connections" to local authorities (Davis, 2003; Reardon et al., 2007).

\section{Income Diversification in Vietnam}

Pederson and Annou (1999), with the 1992-93 Vietnam Living Standards Survey, suppose that a typical household in rural areas is willing to adopt income diversification that is small in farm size, and higher in level of education. Henin (2002) finds that the policy changes to market-orientation stimulate income diversification. Moreover, Castella \& Quang (2002) argue that policy changes also have different effects on income diversification. Specifically, the effect of policy changes on income diversification is only found in uplands, whereas policy changes stimulate intensification in rice production in lowlands. These findings are supported by the work of Fatoux et al. (2002). Furthermore, Alther et al. (2002) highlights the market accessibility as an important factor of income diversification.

\section{c. Analytical Framework:}

The study employs main ideas adopted from literature reviews on theories and empirical studies related to income diversification of households. There are several determinants affecting the diversification and its extensions are classified into the following categories: (i) household's human capital in terms of quantity, physical and educational quality; (ii) household's natural capital represented by land holding; (iii) household's physical assets; (iv) household's financial capital such as of money, mainly savings and borrowings; and v) household's social capital which can be represented by ethnics and other social relationships. In addition, other determinants at meso-level that 
affect income diversification of households such as public infrastructure and availability of financial market are also used in the empirical model.

\section{DATA AND METHODOLOGY}

\section{a. Data:}

The study uses the survey data set of the 2010 Vietnam Household Living Standards Surveys conducted by GSO under the support of World Bank and UNDP. The data set covers around 9,000 households of 8 socio-economic regions including income and expenditures. Only 6,581 rural households are selected for analyses. The surveyed indicators are divided into eight categories, including: (i) Household structure and demographics; (ii) Education; (iii) Health and health care; (iv) Employment and income; (v) Expenditures; (vi) Durable goods; (vii) Housing, electricity, water, sanitation facilities; and (viii) Participation in poverty reduction programs and credit. Overall, income source of a household could be categorized into several sources. Firstly, off-farm self-employment refers to income-generating activities, such as processing goods for sale or providing agricultural services. Secondly, on-farm self-employment regards income-generating activities related to crop, livestock, and aquaculture production. Thirdly, wage employment concerns work for wages in association with agricultural production and industrial/service sectors. Lastly, two remaining income sources are transfer and other income.

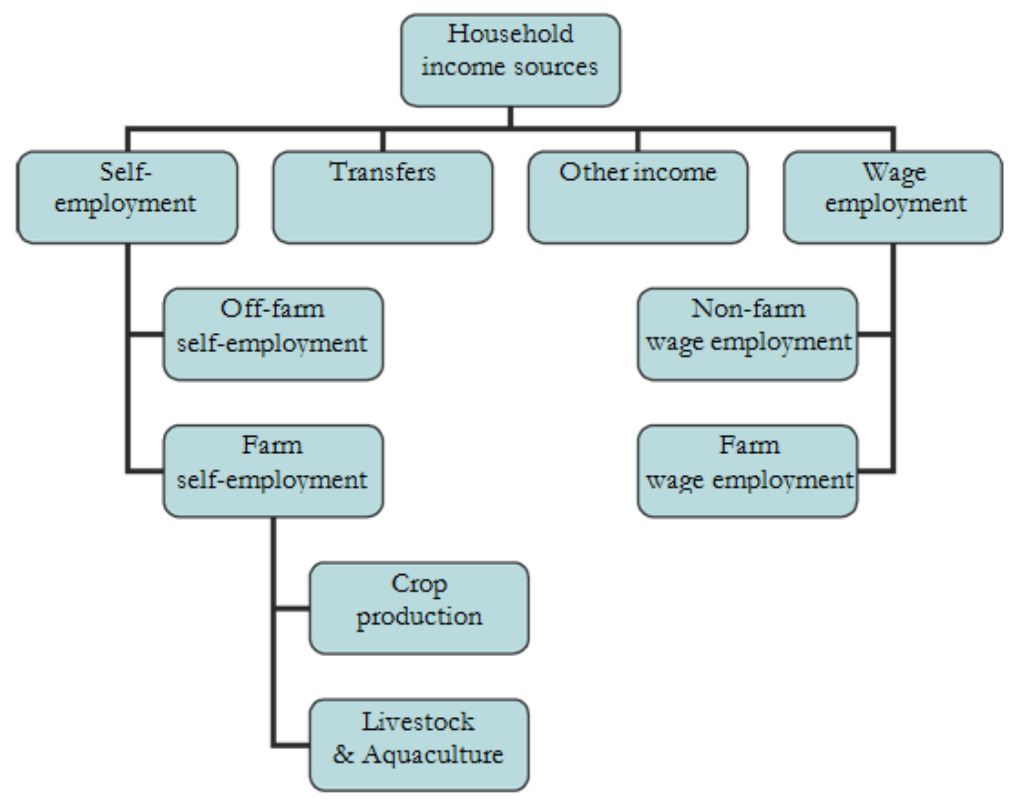




\section{Figure 1: Classification of Household Income Sources in VHLSS 2010}

Source: Le (2010)

\section{b. Data Analysis Methods:}

To answer the first research question, we propose the data analysis procedure as follows:

Step 1: Income diversification Herfindahl-Hirschman index (HHI) is calculated.

$$
H H I=1-H I=1-\sum_{i=1}^{n} P^{2}
$$

where $\mathrm{p}$ is proportion of each income source on total household income. Income diversification index is built, based on the data extracted from VHLSS 2010.

Step 2: Appropriate variables representatives for detecting determinants of income diversification of rural households are identified and selected. Because these variables are representatives for rural household's resources, they probably influence household's income diversification. Other variables are based on experiences from the theories and empirical studies discussed in Section 2.2.

Step 3: Two-limit tobit model is applied to analyze the determinants of income diversification. Since HHI cannot be below zero or above one, a double censored regression model, in particular, a two-limit tobit model is used to analyze the determinants of income diversification. For simplicity, indices for the $i^{\text {th }}$ household and the $\mathrm{j}^{\text {th }} \mathrm{HHI}$ of each household in the sample are not included in the equation.

$$
\begin{aligned}
& \mathrm{S}^{*}=\beta_{0}+\beta_{1} X_{1}+\beta_{2} X_{2}+\ldots+\beta_{\mathrm{n}} X_{n}+u \\
& S=\left\{\begin{array}{lll}
0 & \text { if } & S^{*} \leq 0 \\
1 & \text { if } & S^{*} \geq 1 \\
S^{*} & \text { if } & 0<S<1
\end{array}\right.
\end{aligned}
$$

where $\mathrm{X}_{1}, \mathrm{X}_{2}, \ldots, \mathrm{X}_{\mathrm{n}}$ denote independent variables that have a bearing on time allocation. $\mathrm{S}^{*}$ is a latent variable indicating desired Herfindahl index while $\mathrm{S}$ is the observed Herfindahl index. The relationship between the observed and latent variable 
is provided above, and $\mathrm{u}$ is an error term which is assumed to follow a standard normal distribution.

Since tobit model is used, a decomposition approach suggested by McDonald and Mofitt (1980) may be used to obtain the marginal effects of the independent variables on the outcome. That is, a change in an independent variable has two effects: (i) it affects the conditional mean of $\mathrm{S}^{*}$ in the part of the distribution between 0 and 1 ; and (ii) it affects the probability that the observation will fall in that part of the distribution.

To answer the second research question, the effect of diversification on household income is examined by using GMM estimators. The model specification is presented in Table 2 below:

$$
\mathrm{Y}=\beta_{0}+\beta_{1} X_{1}+\beta_{2} X_{2}+\ldots+\beta_{7} X_{7}+\beta_{8} \text { Herfindahl-index }+u
$$

Thanks to the large number of observation, the model could avoid the multicollinearity. Moreover, to cope with potential endogeneity of Herfindahl index, choosing the plausible instrumental variables is critical. Because of the presence of endogenous explanatory variables (e.g. Herfindahl index), all of the estimates may be biased and inconsistent. The instrumental variables used in this step should meet two conditions: (i) they are correlated (positively or negatively) with endogenous explanatory variables, (ii) instrumental variables are uncorrelated with the disturbance term. In this study, instrumental variables are used as the number of household members working in non-farm activities.

The estimator applied is the generalize method of moments (GMM) because most of the variables in this study are jointly endogenous. In other words, there are the twoway relationships between explanatory variables and dependent ones. Moreover, endogeneity could lead to inconsistent estimates. 
Table 1: Model Specification for Determinants of Household's Income Diversification

\begin{tabular}{|c|c|c|c|}
\hline & Relevant Variables & Variables' Measurement & $\begin{array}{l}\text { Expected } \\
\text { Sign }\end{array}$ \\
\hline $\begin{array}{l}\text { Dependent } \\
\text { Variable }\end{array}$ & $\begin{array}{l}\text { Household's Income } \\
\text { Diversification }\end{array}$ & $\begin{array}{l}\text { Herfindahl-Hirschman } \\
\text { Index }\end{array}$ & \\
\hline \multicolumn{4}{|c|}{ Independent variables } \\
\hline \multirow[t]{7}{*}{$\begin{array}{l}\text { Household } \\
\text { features }\end{array}$} & Household education level & Average schooling year & $(+)$ \\
\hline & Number of sick persons & People in sickness & \\
\hline & Number of health treatment & Number per year & $(+/-)$ \\
\hline & Total cost for treatment & $1000 \mathrm{VND}$ per year & $(+/-)$ \\
\hline & $\begin{array}{l}\text { Number of household members } \\
\text { working non-farm }\end{array}$ & People per household & $(+)$ \\
\hline & $\begin{array}{l}\text { Number of household members } \\
\text { working in others }\end{array}$ & People per household & $(+)$ \\
\hline & $\begin{array}{l}\text { Number of household member } \\
\text { working on-farm }\end{array}$ & People per household & $(-)$ \\
\hline Land resource & Total agricultural cultivated area & $1000 \mathrm{~m}^{2}$ & $(+/)$ \\
\hline \multirow[t]{3}{*}{ Physical asset } & Housing area & $\mathrm{m}^{2}$ & $(+/-)$ \\
\hline & Mobile phone & 1: if yes; 0 : if none & \\
\hline & Motorbike & 1: if yes; 0 : if none & $(+)$ \\
\hline \multirow[t]{2}{*}{ Additional income } & Having credit & 1: if yes; 0 : if none & $(+)$ \\
\hline & Total debt & Debt amount (1000 VND) & \\
\hline \multirow[t]{2}{*}{ Social network } & Ethnicity & $\begin{array}{l}\text { 1: if Kinh and Hoa; } 0 \text { : } \\
\text { otherwise }\end{array}$ & $\left(+/ \_\right)$ \\
\hline & Relationships to public officers & 1: if yes; 0 : none & $(+)$ \\
\hline \multirow[t]{2}{*}{ Regional factors } & Presence of transport road & 1: if yes; 0 : none & $(+/)$ \\
\hline & Presence of private factory & $1:$ if yes; 0 : none & $(+)$ \\
\hline
\end{tabular}


Presence of roadway to centers

1: if yes; 0 : none

Number of natural disaster, disease

occurrence within year number
$(+)$

$(+)$

Table 2: Model Specification for Detecting Effect of Income Diversification on Household Income

\begin{tabular}{|c|c|c|c|}
\hline & Relevant Variables & Variables' Measurement & $\begin{array}{l}\text { Expected } \\
\text { Sign }\end{array}$ \\
\hline $\begin{array}{l}\text { Dependent } \\
\text { Variable }\end{array}$ & $\begin{array}{c}\text { Log (Household's Per Capita } \\
\text { Average Income) }\end{array}$ & & \\
\hline \multicolumn{4}{|c|}{ Independent variables } \\
\hline $\begin{array}{l}\text { Income } \\
\text { Diversification }\end{array}$ & $\begin{array}{l}\text { Household's } \\
\text { diversification }\end{array}$ & $\begin{array}{l}\text { Herfindahl-Hirschman } \\
\text { index }\end{array}$ & $(+/-)$ \\
\hline \multirow[t]{7}{*}{$\begin{array}{l}\text { Household } \\
\text { features }\end{array}$} & Household education level & Average schooling year & $(+)$ \\
\hline & Number of sick persons & People in sickness & \\
\hline & Number of health treatment & Number per year & $(+/-)$ \\
\hline & Total cost for treatment & 1000 VND per year & $(+/-)$ \\
\hline & $\begin{array}{l}\text { Number of household members } \\
\text { working non-farm }\end{array}$ & People per household & $(+)$ \\
\hline & $\begin{array}{l}\text { Number of household members } \\
\text { working in others }\end{array}$ & People per household & $(+)$ \\
\hline & $\begin{array}{l}\text { Number of household member } \\
\text { working on-farm }\end{array}$ & People per household & $(-)$ \\
\hline Land resource & $\begin{array}{l}\text { Log (Total agricultural cultivated } \\
\text { area) }\end{array}$ & $1000 \mathrm{~m}^{2}$ & $(+/-)$ \\
\hline \multirow[t]{3}{*}{ Physical asset } & Housing area & $\mathrm{m}^{2}$ & $(+/-)$ \\
\hline & Mobile phone & 1: if yes; 0 : if none & \\
\hline & Motorbike & 1: if yes; 0 : if none & $(+)$ \\
\hline Additional income & Having credit & $1:$ if yes; 0 : if none & $(+)$ \\
\hline
\end{tabular}


Total debt

\begin{tabular}{llll}
\hline Social Network & Ethnicity & $\begin{array}{l}\text { 1: if Kinh or Hoa; 0: } \\
\text { otherwise }\end{array}$ & $(+/-)$ \\
& Relationships to public officers & 1 : if yes; 0: none & $(+)$ \\
\hline Regional factors & Presence of transport road & 1 : if yes; 0: none & $(+/-)$ \\
& Presence of private factory & 1 : if yes; 0: none \\
& Presence of roadway to centers & 1 : if yes; 0: none \\
& Presence of waterways & 1 : if yes; 0: none \\
& $\begin{array}{l}\text { Number of natural disaster, disease } \\
\text { occurrence within year }\end{array}$ & number & $(+)$ \\
\hline
\end{tabular}

\section{EMPIRICAL FINDINGS}

\section{a. Determinants of Income Diversification:}

This section explores the determinants of income diversification using data of VHLSS 2010. Empirical estimates of unrestricted and restricted tobit models are presented in Table 3 and 4 below.

All independent variables presented in model specification (Table 1) are included in the unrestricted model (Table 3) regardless of multicollinearity among independent variables. The "general to specific" estimation strategy is employed to treat the estimates of the unrestricted model. Insignificant independent variables are excluded one by one to get the restricted model in Table 4 . The insignificant variables are total agricultural land area, number of disaster, number of labors working in others, and number of sick persons. In Vietnam, rural households consist of both farm and nonfarm ones and they often engage in a variety of non-farm activities; and the limit of agricultural land holding of farming households force households' members to look for other activities for additional earnings. Therefore, total agricultural land area has statistically insignificant effect on income diversification index. The fact that number of disaster has no effect on income diversification could be due to its measurement in VHLSS data set. As calculated by number of disaster occurrence within year, that variable probably does not really reflect the seriousness of disaster that forces households to diversify their income source. Meanwhile, collinearity between number of sick persons and such others as total cost of treatments might lead to its insignificant 
influence on income diversification index. Finally, the number of non-farm labors could be a better proxy of non-farm activities than the number of labors working in others. Hence, the latter is not statistically significant.

Concerning the restricted empirical model, effects on income diversification index of the estimates are statistically significant (Table 4). Five variables representing human capital of rural households positively affecting income diversification are average schooling year, number of non-farm labors, number of on-farm labors, number of health treatments within years, and the total cost of treatment within years. These results indicate that human resource quality and quantity of households play a substantial role in directing households to diversified activities. Household's income diversification is stronger as educational level and quantity of labors increase. The positive influence of on-farm labor quantity suggests that in rural areas, households try to make best use of on-farm labor for non-farm additional activities.

In particular, the increase in number of health treatment and cost of health treatment leads to increase in income diversification. When members of households have health problems, they are more likely to look for more diverse activities such as on-farm wage earnings for finding more financial source to cover health treatment costs, or to ease their time allocation for health treatment.

\section{Table 3: Unrestricted Model for Determinants of Income Diversification}

Dependent Variable: HHI

Method: ML - Censored Normal (TOBIT) (Quadratic hill climbing)

Sample: 16581

Included observations: 6571

Left censoring (value) at zero

Convergence achieved after 5 iterations

Covariance matrix computed using second derivatives

\begin{tabular}{lcccc}
\hline \multicolumn{1}{c}{ Variable } & Coefficient & Std. Error & z-Statistic & Prob. \\
\hline Total agricultural cultivated area & $-3.17 \mathrm{E}-08$ & $5.23 \mathrm{E}-08$ & -0.607129 & 0.5438 \\
Total cost of health treatment & $1.45 \mathrm{E}-06$ & $3.59 \mathrm{E}-07$ & 4.046168 & 0.0001 \\
Having credit & 0.044569 & 0.010113 & 4.407144 & 0.0000
\end{tabular}




\begin{tabular}{|c|c|c|c|c|}
\hline Housing area & -0.000223 & $7.06 \mathrm{E}-05$ & -3.162844 & 0.0016 \\
\hline Kinh or Hoa ethnics & -0.016243 & 0.007489 & -2.168954 & 0.0301 \\
\hline Having mobile phone & -0.022293 & 0.006183 & -3.605315 & 0.0003 \\
\hline Having motorbike & -0.026139 & 0.014547 & -1.796838 & 0.0724 \\
\hline Number of non-farm labors & 0.024775 & 0.003312 & 7.480846 & 0.0000 \\
\hline Number of disaster & 0.001758 & 0.001316 & 1.335664 & 0.1817 \\
\hline Number of on-farm labors & 0.061014 & 0.001997 & 30.54567 & 0.0000 \\
\hline Number of health treatment & 0.000437 & 0.000343 & 1.276799 & 0.2017 \\
\hline Presence of transport road & -0.030100 & 0.005104 & -5.897699 & 0.0000 \\
\hline Number of labors working for others & -0.001467 & 0.002510 & -0.584486 & 0.5589 \\
\hline Presence of private factory & -0.017488 & 0.006171 & -2.833824 & 0.0046 \\
\hline Having relationships to public officers & 0.033510 & 0.013027 & 2.572315 & 0.0101 \\
\hline Presence of roadway to centers & 0.048474 & 0.017017 & 2.848490 & 0.0044 \\
\hline Household educational level & 0.003906 & 0.000992 & 3.939103 & 0.0001 \\
\hline Number of sick persons & 0.000726 & 0.001013 & 0.717371 & 0.4731 \\
\hline Total debt & $-3.18 \mathrm{E}-07$ & $5.52 \mathrm{E}-07$ & -0.575914 & 0.5647 \\
\hline Constant & 0.319522 & 0.022703 & 14.07387 & 0.0000 \\
\hline & Error D & stribution & & \\
\hline SCALE:C(21) & 0.198960 & 0.001754 & 113.4409 & 0.0000 \\
\hline Mean dependent var & 0.445801 & \multicolumn{2}{|c|}{ S.D. dependent var } & 0.218932 \\
\hline S.E. of regression & 0.197223 & \multicolumn{2}{|c|}{ Akaike info criterion } & -0.344607 \\
\hline Sum squared resid & 254.7745 & \multicolumn{2}{|c|}{ Schwarz criterion } & -0.322906 \\
\hline Log likelihood & 1153.206 & \multicolumn{2}{|c|}{ Hannan-Quinn criter. } & -0.337105 \\
\hline Avg. log likelihood & 0.175499 & & & \\
\hline Left censored obs & 89 & \multicolumn{2}{|c|}{ Right censored obs } & 0 \\
\hline Uncensored obs & 6482 & \multicolumn{2}{|c|}{ Total obs } & 6571 \\
\hline
\end{tabular}

Source: Authors' calculations based on the VHLSS 2010 


\section{Table 4: Restricted Model for Determinants of Income Diversification}

Dependent Variable: HHI

Method: ML - Censored Normal (TOBIT) (Quadratic hill climbing)

Sample: 16581

Included observations: 6571

Left censoring (value) at zero

Convergence achieved after 4 iterations

Covariance matrix computed using second derivatives

\begin{tabular}{lcccc}
\hline \multicolumn{1}{c}{ Variable } & Coefficient & Std. Error & z-Statistic & Prob. \\
\hline Having credit & 0.040448 & 0.007081 & 5.712018 & 0.0000 \\
Household educational level & 0.003846 & 0.000988 & 3.894150 & 0.0001 \\
Housing area & -0.000225 & $7.04 \mathrm{E}-05$ & -3.201845 & 0.0014 \\
Kinh or Hoa ethnics & -0.016472 & 0.007461 & -2.207686 & 0.0273 \\
Having mobile phone & -0.022275 & 0.006165 & -3.613084 & 0.0003 \\
Having motorbike & -0.026370 & 0.014508 & -1.817537 & 0.0691 \\
Number of non-farm labor & 0.025099 & 0.003241 & 7.743680 & 0.0000 \\
Number of on-farm labor & 0.061149 & 0.001983 & 30.84047 & 0.0000 \\
Number of health treatment & 0.000547 & 0.000281 & 1.944315 & 0.0519 \\
Total cost of health treatment & $1.48 \mathrm{E}-06$ & $3.56 \mathrm{E}-07$ & 4.146668 & 0.0000 \\
Presence of transport road & -0.030194 & 0.005103 & -5.917103 & 0.0000 \\
Presence of private factory & -0.017511 & 0.006155 & -2.845219 & 0.0044 \\
Having relationships to public officers & 0.032105 & 0.012879 & 2.492892 & 0.0127 \\
Presence of roadway to centers & 0.046785 & 0.016948 & 2.760441 & 0.0058 \\
Constant & 0.324135 & 0.022355 & 14.49957 & 0.0000 \\
\hline
\end{tabular}

Error Distribution

\begin{tabular}{lcccc}
\hline SCALE:C(16) & 0.199010 & 0.001754 & 113.4407 & 0.0000 \\
\hline Mean dependent var & 0.445801 & S.D. dependent var & 0.218932
\end{tabular}




\begin{tabular}{llll} 
S.E. of regression & 0.197194 & Akaike info criterion & -0.345615 \\
Sum squared resid & 254.8939 & Schwarz criterion & -0.329081 \\
Log likelihood & 1151.519 & Hannan-Quinn criter. & -0.339900 \\
Avg. log likelihood & 0.175243 & & \\
\hline Left censored obs & 89 & Right censored obs & 0 \\
Uncensored obs & 6482 & Total obs & 6571 \\
\hline
\end{tabular}

Source: Authors' calculations based on the VHLSS 2010

Having credit is the proxy of household financial capital. This variable positively affects income diversification index, which suggests that credit accessibility helps enhance household income diversification. Credit can be used for investment in both traditional income-creating activities and new and diverse activities.

In terms of physical assets, housing area negatively affects income diversification index. It could be due to the fact that housing area reflects types of households' main activities. Normally, farming households often have higher housing area for agricultural product drying and storage while non-farm households do not necessarily have big housing area for such purposes. In this sense, therefore, larger housing area probably implies that farming households often have less income diversification.

The households in connection with public officers are in advantage when such relationships can bring them better chances of income diversification. It is obviously because better social capital can help people obtain more information and social aid.

The households living in the regions with better roadway to centers can obtain higher likelihood of income diversification. Improved infrastructure, especially roads to provincial and/or district centers probably open the chance of increasing non-farm activities for people.

However, the empirical estimates also show unexpected effects of some variables on income diversification index, such as having mobile phone and motorbike; household's ethnicity; presence of transport road; and the presence of private factory in the location. There remain unsurely explanations and difficult concerns. Having mobile phone and motorbike are expected to positively affect income diversification because it means better communication and information as well as improvement of individual mobility. Similarly, the empirical estimates show that Kinh or Hoa ethnics are likely to 
be less diversified while, in reality, ethnic minorities are more subsistence-oriented and resistant to new ways of earning living because of their personalities and/or cultural values. In the same sense, when the community has transport road and private factory, the probability of income diversification reduces. It seems that the impact of community infrastructure on income diversification is mixed as found in some previous studies (Haggblade, Hazell \& Reardon, 2002; Reardon, 1997; Escobal, 2001; Lanjouw \& Lanjouw, 2001). The contrast of these findings to the expectations is hard to interpret and hence, is considered as a limitation of this study.

\section{b. Effects of Income Diversification on Household Income:}

This section explores the effect of income diversification on rural household income. The empirical estimates are presented in Table 5 below. The instrumental variable in use is number of non-farm labors. The estimator applied is GMM to cope with the potentially joint endogeneity of most variables involved. The average household income and the total area of agricultural land are taken in logarithm to measure the change in percentage of total area of agricultural land that leads to the change in percentage of average household income.

\section{Table 5: Effects of Income Diversification on Household Income}

Dependent Variable: Logarithm of Average Household Income

Method: Generalized Method of Moments

Sample: 16581

Included observations: 5412

Estimation weighting matrix: Two-Stage Least Squares

Standard errors \& covariance computed using estimation weighting matrix

Instrument specification: NUMBER_NON_FARM WATER_WAY

SCHOOLING_YEAR/HHSIZE C LOG(AGRICULTURAL_LAND_AR

EA) KINH_HOA SICK_PERSON ROADWAY REMOTE_AREA

ROADWAY_CENTER PRIVATE_SECTOR

\begin{tabular}{|c|c|c|c|c|}
\hline Variable & Coefficient & Std. Error & t-Statistic & Prob. \\
\hline Constant & 6.754041 & 0.246434 & 27.40714 & 0.0000 \\
\hline HHI (instrumental variable) & 3.409584 & 0.611386 & 5.576814 & 0.0000 \\
\hline
\end{tabular}




$\begin{array}{lllll}\text { Household educational level } & 0.067701 & 0.005387 & 12.56678 & 0.0000 \\ \text { Logarithm of total agricultural land area } & -0.001722 & 0.015489 & -0.111164 & 0.9115 \\ \text { Kinh or Hoa ethnics } & 0.532778 & 0.052723 & 10.10517 & 0.0000 \\ \text { Number of sick persons } & 0.005617 & 0.004337 & 1.295117 & 0.1953 \\ \text { Presence of transport roadway } & 0.084188 & 0.045494 & 1.850523 & 0.0643 \\ \text { Remote area } & -0.095708 & 0.033213 & -2.881642 & 0.0040 \\ \text { Presence of roadway to centers } & -0.228518 & 0.105709 & -2.161772 & 0.0307 \\ \text { Presence of private factory } & 0.240413 & 0.034724 & 6.923537 & 0.0000 \\ \text { Presence of waterway } & 0.176212 & 0.045560 & 3.867666 & 0.0001 \\ \text { R-squared } & -1.067429 & \text { Mean dependent var } & 9.240667 \\ \text { Adjusted R-squared } & -1.071257 & \text { S.D. dependent var } & 0.673004 \\ \text { S.E. of regression } & 0.968578 & \text { Sum squared resid } & 5066.908 \\ \text { Durbin-Watson stat } & 1.519973 & \text { J-statistic } & & 17.21897 \\ \text { Instrument rank } & 12 & \text { Prob(J-statistic) } & 0.000033\end{array}$

Source: Authors' calculations based on the VHLSS 2010

As presented in the Table 5, the R-squared of the empirical model is negative; therefore, its conventional interpretation is lacked [1]. Nevertheless, the estimates allow the conclusion that income diversification index has very strong effect on household income in rural Vietnam. This finding is consistent with both theories and previous studies as in Delgado and Siamwalla (1997). The results also show a clear positive association between average schooling year and average household income. It means that households with higher educational levels enjoy higher income in general or improvement of rural education is probably a good way to increase household income.

The insignificant effect of agricultural land area on household income again confirms that in rural Vietnam, the legal limit of landholding does not allow rural households to increase their income in general. Meanwhile, diversifying income source though non-farm activities strongly helps improve household income. The Kinh and Hoa households are more likely to get higher earnings than other minorities. The households living in remote areas are likely to have less income. 
The estimates of community characteristics as waterway and roadway show mixed effects on household income. It might be due to the deep differences in geographical characteristics and development level of infrastructure in rural regions of Vietnam. Nevertheless, the presence of private manufacturing sector in community tends to help increase household income in that community.

\section{CONCLUSION AND RECOMMENDATION}

The results demonstrate some important findings about determinants of income diversification, and the effect of income diversification on rural household income. Human capital in both quantity and quality dimensions plays a substantial role in encouraging rural households to diversify their income-created activities. Rural households with higher education level, and more diversification ability tend to be more diversified in income source. Owning better financial capital or credit accessibility and social capital helps rural households improve income diversity.

The study results also confirm that income diversification is the dynamics of rural income. Households can increase their income through diversifying their farm and non-farm activities.

The study has faced difficulty in interpreting unexpected effects of some factors. In particular, infrastructure seems to have mixed effects on both income diversification and household income in rural Vietnam. It is likely that regional features have potential influences on differences in infrastructure investment and development level in rural Vietnam. Therefore, variables indicating regional characteristics should be considerately employed to improve validity of empirical estimates.

The findings lead to policy implications that better providing fair educational and healthcare services in rural is a significant solution to support income diversification and increase household income via human capital improvement. Policies that help diversify sources, increase volume of rural credit, and ease accessibility to credit is promising to increase diversification and income of rural households. Although the effect of better infrastructure in rural areas on income is not well confirmed, we believe that they are basic physical facilities to serve for better educational and healthcare services and support generation of non-agricultural activities accordingly 


\section{Note:}

[1] As Wooldridge (2012) mentioned in his textbook, "Unlike in the case of OLS, the R-squared from IV estimation can be negative because SSR for IV can actually be larger than SST. Although it does not really hurt to report the R-squared for IV estimation, it is not very useful, either".

\section{References}

Abdulai, A. \& A. CroleRees (2001), "Determinants of Income Diversification amongst Rural Households in Southern Mali”, Food Policy, 26(4): 437-452.

Alther, C., J.C. Castella, P. Novosad, E. Rouseau \& Tran Trong Hieu (2002), "Impact of Accessibility on the Range of Livelihood Options Available to Farm Households in Mountainous Areas of Northern Viet Nam" in J. C. Castella \& Dang Dinh Quang (eds.), Doi Moi in the Mountains: Land Use Changes and Farmers' Livelihood Strategies in Bac Kan Province, Viet Nam, Hanoi: Agricultural Publishing House, 121-146.

Barrett, C.B. \& T. Reardon (2001), "Asset, Activity, and Income Diversification Among African Agriculturalists: Some Practical Issues”, Food Policy, 26(4): 315-331.

Barrett, C., M. Bezuneh \& A. Aboud ( 2001), "Income Diversification, Poverty Traps, and Policy Shocks in Côte d'Ivoire and Kenya", Food Policy, 26: 367-384.

Barrett, C., M. Bezuneh, D. Clay \& T. Reardon (2000), Heterogeneous Constraints, Incentives, and Income Diversification Strategies in Rural Africa, Broadening Access and Strengthening Input Market Systems, Madison, Wisc.: University of Wisconsin.

Barrett, C.B., T. Reardon \& P. Webb (2001), "Nonfarm Income Diversification and Household Livelihood Strategies in Rural Africa: Concepts, Dynamics, and Policy Implications", Food Policy, 26: 315-331.

Block, S. \& P. Webb (2001), "The Dynamics of Livelihood Diversification in Post-Famine Ethiopia”, Food Policy, 26: 333-350.

Carney, D., M. Drinkwater, T. Rusinow, K. Neefjes, S. Wanmali \& N. Singh. (1999), "Livelihoods Approaches Compared", paper presented at the Conference "Natural Resources Advisers", UK Department for International Development (DFID).

Castella, J.C. \& Dang Dinh Quang (eds.) (2002), Doi Moi in the Mountains: Land Use Changes and Farmers' Livelihood Strategies in Bac Kan Province, Viet Nam. Hanoi: Agricultural Publishing House.

Castella, J.C., Tran Quoc Hoa, O. Husson, Vu Hai Nam \& Dang Dinh Quang (2000), “The Declining Role of Ethnicity in Farm Household Differentiation: A Case Study from Ngoc Phai Commune, Cho Don District, Bac Kan Province, Viet Nam” in J. C. Castella \& Dang Dinh Quang (eds.), Doi Moi in the Mountains: Land Use Changes and Farmers' Livelihood Strategies in Bac Kan Province, Viet Nam, Hanoi: Agricultural Publishing House. 
Davis, J.R. (2003), "The Rural Non-farm Economy, Livelihoods and their Diversification: Issues and Options", NRI Report to Department for International Development and World Bank No. 2753.

Davis, J.R. \& D. Bezemer (2003), "Key Emerging and Conceptual Issues in the Development of the RNFE in Developing Countries and Transition Economies", NRI Report to Department for International Development and World Bank No. 2753.

Delgado, C. \& A. Siamwalla (1997), "Rural Economy and Farm Income Diversification in Developing Countries", Discussion Paper No. 20, Markets and Structural Studies Division. Washington, D.C.: International Food Policy Research Institute.

Dercon, S. (1998), "Wealth, Risk and Activity Choice: Cattle in Western Tanzania", Journal of Development Economics, 55(1): 1-42.

Dercon, S. \& P. Krishnan (1996), "Income Portfolio in Rural Ethiopia and Tanzania: Choices and Constraints", Journal of Development Studies, 32(6): 850-875.

Dunn, E. (1997), "Diversification in the Household Economic Portfolio", Washington, D.C.: Office of Microenterprise Development, USAID.

Ellis, F. (1998), “Household Strategies and Rural Livelihood Diversification”, Journal of Development Studies, 35(1): 1-38.

Ellis, F. (2000), Rural Livelihoods and Diversity in Developing Countries, New York: Oxford University Press.

Ersado, L. (2003), "Income Diversification in Zimbabwe: Welfare Implications from Urban and Rural Areas", FCND Discussion Paper 152, Washington, D.C.: International Food Policy Research Institute.

Escobal, J. (2001), "The Determinants of Nonfarm Income Diversification in Rural Peru", World Development, 29(3): 497-508.

FAO (1998), State of Food and Agriculture 1998, Rome: FAO.

Fatoux, C., J. C. Castella, M. Zeiss \& Pham Hung Manh (2002), "From Rice Cultivator to Agroforester within a Decade: The Impact of Doi Moi on Agricultural Diversification in a Mountainous Commune of Cho Moi District, Bac Kan Province, Viet Nam” in J. C. Castella \& Dang Dinh Quang (eds.), Doi Moi in the Mountains: Land Use Changes and Farmers' Livelihood Strategies in Bac Kan Province, Viet Nam, Hanoi: Agricultural Publishing House.

Gulati, A., N. Minot, C. Delgado, \& S. Bora (2005), "Growth in High-Value Agriculture in Asia and the Emergence of Vertical Links with Farmers", Paper presented at the Symposium "Toward High- Value Agriculture and Vertical Coordination: Implications for Agribusiness and Smallholders", National Agricultural Science Centre, Pusa, New Delhi, March 7, 2005.

Haggblade, S., P. Hazell \& T. Reardon (2002), "Strategies for Stimulating Poverty-Alleviating Growth in the Rural Non-farm Economy in Developing Countries", International Food Policy Research Paper.

Henin, B. (2002), “Agrarian Change in Vietnam's Northern Upland Region”, Journal of Contemporary Asia, 32(1): 3-28. 
Joshi, P. K., A. Gulati, P. S. Birthal \& L. Twari (2003), "Agricultural Diversification in South Asia: Patterns, Determinants, and Policy Implications", Discussion Paper No.57, Markets and Structural Studies Division, Washington, D.C.: International Food Policy Research Institute.

Lanjouw, P. \& G. Feder (2001), Rural Non-Farm Activities and Rural Development: From Experience Towards Strategy, The World Bank’s Rural Development Strategy Background Paper no. 4.

Lanjouw, J. \& P. Lanjouw (2001), “The Rural Non-Farm Sector: Issues and Evidence from Developing Countries", Agricultural Economics, 26: 1-13.

Lê Tấn Nghiêm (2010), “Activity and Income Diversification: The Case of The Mekong River Delta", doctoral dissertation, Rotterdam University

Minot, N., M. Epprecht, T.T.T. Anh \& L.Q. Trung (2006), Income Diversification and Poverty in the Northern Uplands of Vietnam, Washington, DC: International Food Policy Research Institute.

Omamo, S. (1998), "Transport Costs and Smallholder Cropping Choices: An Application to Siaya District, Kenya", American Journal of Agricultural Economics, 80 (February): 116-123.

Pederson, G. \& M. Annou (1999), "Rural Household Income Diversification in Viet Nam”, Quarterly Journal of International Agriculture, 38(2): 140-149.

Reardon, T. (1997), "Using Evidence of Household Income Diversification to Inform Study of the Rural Nonfarm Labor Market in Africa”, World Development, 25(5): 735-747.

Reardon, T., J. Berdegué, C.B. Barrett \& K. Stamoulis (2007), "Household Income Diversification into Rural Nonfarm Activities" in S. Haggblade et al. (eds), Transforming the Rural Nonfarm Economy: Opportunities and Threats in the Developing World (115-140), Baltimore: Johns Hopkins University Press.

Reardon, T., P. Matlon \& C. Delgado (1988), "Coping with Household-Level Food Insecurity in DroughtAffected Areas of Burkina Faso”, World Development, 16(9): 1065-1074.

Reardon, T., C. P. Timmer \& J. A. Berdegue (2003), "The Rise of Supermarkets in Latin America and Asia: Implications for International Market for Fruits and Vegetables" in A. Regmi \& M. Gehlhar (eds.), Global Markets for High Value Food Products, Agriculture Information Bulletin, USDA-ERS.

Singh, I., L. Squire \& J. Strauss (eds.) (1986), Agricultural Household Models: Extensions, Applications, and Policy, Baltimore: Johns Hopkins University Press.

Start, D. \& C. Johnson (2001), "Transformation, Well-Being and the State: Rural Livelihood Diversification in South Asia", ODI Working paper.

Walle, D. van de \& D. Cratty (2004), "Is the Emerging Non-farm Market Economy the Route Out of Poverty in Vietnam?", The Economics of Transition, 12(2): 237-274.

Wooldridge, J. (2012), Introductory Econometrics, MIT Press, Cambridge. 